\title{
WORK VALUES AS MODERATOR IN PERSONALITY DIMENSIONS AND ENGAGEMENT OF GEN - Z
}

\author{
Anita Singh ${ }^{1}$, Lata Bajpai Singh ${ }^{2}$ and J Satpathy ${ }^{3}$ \\ ${ }^{1}$ Professor School of Law, Sharada University, Greater Noida, India \\ ${ }^{2}$ Assistant Professor, Babasaheb Bhimrao Ambedkar University, Lucknow, India \\ ${ }^{3}$ Professor, Srinivas University, India and Visiting Professor, Management University of \\ Africa, Nairobi, Kenya
}

\begin{abstract}
There is a change in the work values of social generations i.e., Baby Boomers, Generation Xers and Millennial. Limited study has been conducted on work values of Gen Z. The emphasis of this study is to examine the interaction effect of work values in the association between personality dimensions and engagement. In this study validated instruments were used to collect the primary data from entry level working professionals, who recently joined organizations after completion of their post graduate course. The primary data collected from 208 respondents was analysed using correlation and multiple regression statistical techniques. The result indicates that there is a significant association between extraversion, openness to experience and agreeableness between work values, and engagement. Further, it was identified that there is an adverse association between neuroticism and engagement. A significant affirmative relationship between work values and engagement was also observed. It was further observed that there is a moderating effect of work values on the association between the four elements of personality including openness to experience, extraversion, agreeableness and neuroticism, and engagement. There is a limited study based on the causal association between personality dimensions, engagement attributes and work values on generation $Z$ in India that created the scope for the present study. This study will provide an insight into the work values of Gen $Z$ and provide actionable recommendations to managers in strategic decision making at the workplace.
\end{abstract}

Key Words: Personality Dimensions, Work Value, Engagement, India, Generation Z.

\section{Introduction}

Today's work environment is rapidly changing with the enormous growth in technological capabilities due to exponential enhancement in computing power, internet connectivity and other digital advances. In this digital world, it is pertinent for employees to understand that they are required to deliver speedy work with flexible approach and work with less certainty around outcomes, and supposed to work more effectively in teams. They have to understand that it has become necessary to acquire new skills and updated knowledge of new digital technologies for the success. They also need to have a very different approach towards the work - often referred to as the digital mind set. Generation Z born in between 1996-2010 (Bascha, 2011; Brue Tulgan and Rain maker Inc., 2013) has accelerated the growth of digitalisation. Hughes (2020) 
describes Generation $\mathrm{Z}$ as being tech-savvy, pragmatic, and they enjoy personalized training and attention from their seniors'. Gen $\mathrm{Z}$ was born in an internet era understands digitalisation, what it looks and feel like. For them technology, is not only a means to achieve task rather an important element of everyday life. They are more dependent on the internet for solutions of their problems (Andrea, Gabriella, Timea, 2016, Teresa Bridges, 2015) and as compared to millennial they would like to face more challenges and are agile and impatient.

In this era of digitalisation Generation $\mathrm{Z}$ is considered to be the most suitable workforce as or they are well versed with technical know-how and career oriented. They aspire for stable work environment and would like to maintain work life balance (Andrea, Gabriella, Timea, 2016). Gen $\mathrm{Z}$ is of the opinion that the skills required today at the workplace is very different from the skills required in the past or by previous generations. They are ready to adapt a new array of occupations in the digital economy. Thus, it is necessary to optimise and accelerate digitalisation.

Gen $\mathrm{Z}$ being the young workforce with energy and technology knowhow is very important to achieve the goals of the organisation. One of the major issues with Gen $\mathrm{Z}$ is their retention span. Since they are adaptable to change, they do not have any fear in switching jobs. The organization needs to have a sound HR practices and evaluation process for evaluating the performance of the young workforce. Now organisations are shifting from traditional ways of evaluating their employees to new methods of performance evaluation. The reason behind this shift is the outcome of change in the attitude of Gen $\mathrm{Z}$ towards the work values; they value passion for work and put emphasis on the purpose of the task, they prefer flexibility, transparency, trust, autonomy and collaboration (Bond 2016). The organisation needs to rethink and redesign the existing organisation structures (Ghura, 2017).

The workforce performance is coherent with the organisational performance. Now a day's organisation considers employee engagement as one of the significant criteria for performance assessment and also helps in aligning the individual work values with the organizational values. Various research confirms high level of engagement among employees enhances job performance, task performance, productivity level of the organisation, organisational citizenship behaviour, discretionary effort, affective and continuance commitment, levels of psychological climate, and customer service (Christian et al., 2011; Fleming and Asplund, 2007; Rich et al., 2010; Richman, 2006: Macey and Schneider, 2008; Holbeche and Springett, 2003; Leiter and Bakker, 2010). Research suggests that work engagement is positively linked to work performance. Further engagement has been related with motivational state that leads to higher job performance of the employees (Kahn, 1990; Rich, Lepine, and Crawford, 2010; Schaufeli, Salanova, González-Romá, and Bakker, 2002; Rana et.al 2019).

There are various factors responsible for engagement of the employees at workplace and their work values like work environment, leadership, team and co-worker relationship, training and career development, compensation or remuneration, and workplace wellbeing. These factors may be an individual, a group or organizational specific. Among individual aspect, personality factors play an important role in inculcating engagement and work values of the employees. 
The primary emphasis of the study is to explore the association between personality dimensions with work values and engagement. The aim is also to appraise the moderating effect of work values on the association between personality dimensions and engagement. This study will provide an insight and will benefit not only to academicians but also to corporate, practitioners and consultants for making useful decisions and policy making related to human resource management.

\section{Literature Review}

\section{Personality}

Kinicki (2008) opined that personality is a stable set of characteristics responsible to identity a person. Further he is of the opinion that though personality dimensions are generally controlled by outside, it strongly influences the attributes and expectations of an individual towards others, and thus influences behaviour. Personality traits refer to the structure and natural tendency of an individual that reflects his or her thought patterns, emotion and behaviour (Colquitt, 2009).

A study conducted by Malcolm Higgs, Scott Lichtenstein (2011) provide insight into the relationship between two aspects of individual difference i.e. values and EI and shows a clear relationship between behaviour and performance. Inceoglu and Warr, (2011) is of the opinion that there are different triggers to motivate individuals with different personality traits, depending on the employee's situations and resources. It was also identified that individuals having different personality traits have different motivation process (Goldberg, 1992). Internal locus of control has positive association with student engagement (Singh et al., 2020) and employee working in the organization (Tripathi et al., 2020).

\section{Big Five Personality Dimensions}

The most famous models narrate the characteristics of personality in the "big five" personality framework (Goldberg, 1981, 1990; Costa and McCrae, 1992; John and Srivastava, 1999). The five factors of the big five personality dimensions are Extraversion, agreeableness, conscientiousness, openness, and neuroticism (Costa and McCrae, 1992; McCrae and Jsadnessohn, 1992; John and Srivastava, 1999). Extraversion represents positive feelings (emotions) and seeks affiliation of others. This factor of the personality indicates that people are sociable, assertive, active, upbeat, cheerful, optimistic and talkative. According to Costa and McCrae (1992); John and Srivastava (1999), individuals prefer to work in groups, enjoy excitement and experience positive energy and zeal. Further they reveal that Agreeableness in a personality reflects an individual's tendency to trust others; they are compliant, caring, generous, considerate and gentle. They are optimistic in nature and are sympathetic to others and they are helping others and expect others also to help.

Conscientiousness indicates that the person is purposeful and determined and has a tendency to work dutifully, show self- discipline and strive to achieve above expectation. They demonstrate job and goal directed behaviour, like thinking before acting, backing norms and rules and have a tendency to plan, organise and prioritize the tasks (John and Srivastava, 1999). 
Neuroticism asses the persistency between emotional adjustment and emotional mal adjustment (Costa and McCrae, 1992). High level of Neuroticism in an individual indicates fear, nervousness, sadness, anger, guilt and tension. Low level indicates emotionally stable, and even-tempered person (Costa and McCrae, 1992; John and Srivastava, 1999). It was also observed that the Openness to experience indicates the tendency of a person to be imaginative, creative, sensitive, and original in thinking, appreciative of art, sensitive to beauty and intellectually curious.

\section{Personality and Engagement}

According to Kahn individual difference matters in the engagement of the employees and the personal side of the engagement may be reflected from the sources such as age, gender, ethnicity. A Study by Inceoglu and Warr, 2011, suggests that five major traits of five factor model may be considered as drivers for the work engagement. It has been experienced in the previous research that personality traits impact engagement at work. It demonstrates that certain traits from the Big Five model will either enhance or reduce the engagement level at work.

The study conducted by Langelaan et al. (2006) suggests that individuals who are highly engaged may be classified as Neuroticism and Extraversion as per the Big Five personality traits. It was observed that high scores for Extraversion predicted work engagement whereas low scores for Neuroticism, explained that there is an association between these traits. Further, it suggests that 'Affect' can be narrated as short-term, and individuals experience affirmative emotions when the degree of Extraversion is high whereas individual with a high degree of Neuroticism tends to experience adverse emotions (Watson, 2000). As engagement contemplates positive affective-motivational state, it indicates that for the engagement it is important for a person's tendency to experience affirmative or adverse emotions.

According to Macey and Schneider (2008), there is also a relation between Conscientiousness and engagement. It implies that people with conscientious traits are hardworking, and they have magnitude for dedication and absorption at job. It was observed in a study by Kim, Shin and Swanger (2009) that there is an affirmative association between engagement and openness to experience (Srivastava and Bajpai, 2020), conscientiousness; and has an adverse relationship with Neuroticism (Srivastava and Bajpai, 2020). Further it is attributed to the association of Conscientiousness to the achievement and has striving tendency of individuals, high on the dimension. It was observed that there is no significant association with Extraversion, Agreeableness, and Openness to Experience. Finally, two unique foretellers of job engagement for the big five dimensions are emotional stability and conscientiousness (Inceoglu and Warr, 2012).

\section{Work Values}

Values influence both actions and reactions of an individual. According to Lichtenstein, Scott and Lichtenstien, G. and Higgs, (2017), Leaders strategic decision choices reflect their value orientation. Work values, plays an important part in an individual's life and career development (Rosenberg, 1957; Super, 1990).Researchers have defined work values from different 
perspectives such as the notion of action or belief of action about the value for various work features, constellations of attitudes and opinions (Pennings, 1970,Kluckhohn, 1951; Lewin, 1951; Rokeach, 1973; Olson and Zanna, 1993; Lesthaeghe and Moors, 2000); as attitudes, tendencies , or beliefs(Locke ,1976; Levy and Guttman, 1976; Hofstede, 1980;Ye, 2015); results based on assessment of occupational work(Brown, 1996), further, it can be defined on the basis of estimation as the assessment of the goal or behavior(Ye, 2015); value given to the outcome in the work context(Elizur,1984), some researchers analyze on the basis of the structure of the values (Rokeach, 1973; Schwartz, 1994);two-dimensional, three-dimensional, four-dimensional, five-dimensional, and multidimensional.

Research suggests that work values differ in different generations (Dries, Pepermans and De Kerpel; 2008; Ye, 2015; Simmons, 2018). According to Jaskyte (2014) work values can differ between individuals within the generation itself. If it is seen from the human resource management perspective the distinction in the work can be observed on the basis of extrinsic and intrinsic values (Ryan and Deci, 2000).Extrinsic work values put emphasis on the job outcome where employees are appreciated with tangible rewards such as salary, prestige or job security which are more related with the economic nature of the work whereas Intrinsic values focus on the work outcome associated with appetitive stimulus or rewards like recognition, opportunity for growth and flourishing (Bakker and Oerlemans, 2012; Lyons et al. (2010);Spreitzer and Porath,(2014) and social factors (social communication).

A study conducted by Yuanjie Bao and Wei Zhong (2020) suggests six work value dimension as intrinsic which includes seven values (challenge, change and variety, creativity, use the abilities, interesting, intellectually stimulating, and contribution), achievement that includes three values (fulfilling, accomplishment, and advancement), social which includes three values (fairness, co-workers, and feedback), status that includes three values (job security, prestigious, and physical setting), freedom that includes four values (hours of work autonomy, work alone, and balance between work and life), and extrinsic that includes two values (benefits and salary). Thus, it can be concluded that extrinsic and intrinsic work values may lead to work motivation.

\section{Engagement}

Job engagement is a positive concept and is very common among the companies and consulting firms (Wefald and Downey, 2009). Research suggests that alignment of job satisfaction and job contribution is directly proportional to employee engagement (Singh, 2017) and managers should identify the methods to align the employee's value, goal and aspirations with those of the organisation. The engaged employee has a line of sight and their own future is aligned with the mission and goal of the organisation (Singh and Shukla, 2012).

Usually, the concept of engagement is attributed to Kahn (1990), according to him engagement is "harnessing of organization members" to their work roles". Further he proposes that engaged individuals are characterised by substantially, cognitively vigilant and psychologically related with their work. Similar definition is proposed by Roberts and Davenport, 2002, according to them, it is an individual enthusiasm and his or her involvement in the task; they manage to work harder and are more productive as compared to others. Engaged employees are motivated to learn when the organisations provide support and shares 
the vision of the organisation with them (Singh and Shukla, 2019). Further they are motivated by the task and tend to produce results as per the organization needs. Customer satisfaction, retention, productivity and profitability are the desirable outcome of the job engagement (Buckingham and Coffman, 1999; Luthans and Peterson, 2002).

The best supported model proposed by Bakker and colleagues actualise engagement as a affirmative and affective-motivational state of work-related well-being, itis fulfilling, and characterised by vigour, dedication and absorption (Bakker, Schaufeli, Leiter, 2008). Vigour is represented by a high level of energy and mental resilience while working, not being easily fatigued etc. Dedication represents a sense of significance from one's work, and feeling enthusiastic and proud of one's job. Absorption represents the total involvement of an individual in the task and feels difficult to detach from it. Later on, Liu (2016) suggested five dimensions of employee engagement in the study conducted on knowledge workers: organizational identity, dedication, absorption, vigoro, pleasant harmony.

\section{Theoretical Frame Work and Hypothesis Development}

Self-determination theory (SDT) is an experimentally acquired theory of human motivation and it is also considered as a relevant growth in the gist of Maslow's self-actualization theory (Ryan and Deci, 2000). This particular theory of motivation popularly implemented as the derivative theory of human motivation and behaviour in social environment (Deci and Ryan, 2012). The theory explains that individuals are intrinsically inspired for engaging in any action due to concern and outcomes related to actions. There rests an analogy between intrinsic motivation and self-determination (Ryan and Deci, 2000). The theory also emphasizes on two processes through which such internalizations take place, one is introjections and the other is integration (Deci et al. 1994). The process of introjections includes a foremost procedure, however, not accepting it as one's own whereas combination is related to the guideline which is integrated with one's own core wisdom. The term introjections, indicates governing directives, whereas integration results in self-determination.

Based on the objective of the study following model is proposed by the researcher:

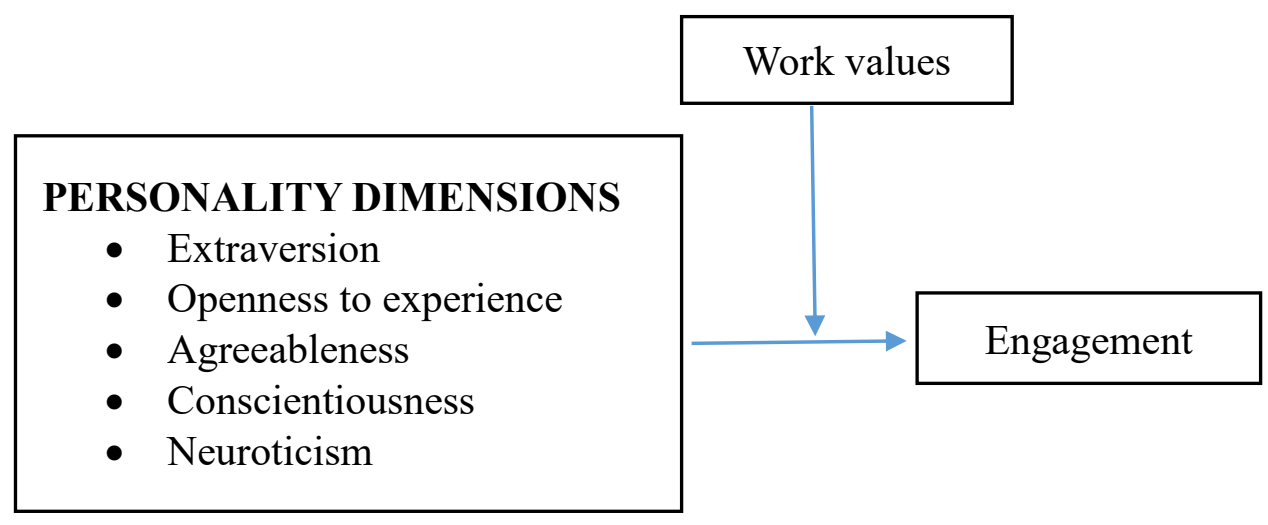

Figure 1: Conceptual Model 


\section{Personality Dimensions and Work Values}

Personality traits play a pertinent role in work-related behaviour and values. It has regained the interest of researchers in the past decade (Judge, Higgins, Thoresen, and Barrick, 1999; Nikolaou and Robertson, 2001). It is advised that the organisations should take proper care of the constellation of values that is possessed by their managers and continuously appraise the goodness of fit with their changing strategic profile. It is expected that the constellation of values will change overtime with the managers age and the population of the managers (Yvonne Guerrier, Keith Macmillan,1981).

Several research has been led by the researchers to observe the association between personality traits, work satisfaction and work values. The researchers have used three- and fivedimensional model and Big Five, higher -order, the dimensions/elements of personality like Extraversion, Neuroticism, Agreeableness, Openness and Conscientiousness and have contended that personality dimensions' impact work values. It has been observed that extraverts see assignments with variety and neurotics prefer assignments with stability. In research conducted by Furnham, Forde, and Ferrari (1999) on job applicants who completed the Eysenck Personality Profiler, identified Extraversion was related to the motivator /intrinsic composite whereas neuroticism was related to the hygiene/extrinsic composite. Further, Furnham et al. (2002) identified conscientiousness as the best forecaster of work values. It has been also observed that openness and conscientiousness several time reflects opposite impacts (Le Pine, Colquitt, and Erez, 2000). Sometimes in the presence of conscientiousness, work outcomes are reduced due to the influence of openness. Similar type of compensatory interaction has been observed between other factors affecting performance (Coté and Miners, 2006) In this study investigation is done to identify extent to which personality dimensions' influence work values of generation $\mathrm{Z}$ in India.

H1.1: There is a significant relationship between extraversion and work values

H1.2: There is a significant relationship between openness to experience and work values

H1.3: There is a significant relationship between agreeableness and work values

H1.4: There is a significant relationship between conscientiousness and work values

H1.5: There is a significant relationship between neuroticism and work values

\section{Personality Dimensions and Engagement}

- Recent research reflects that the work engagement is characterised as an affirmative, persistent calm state of mind. It indicates an affective -motivational state of well-being that relate to work and is not associated with any object or person (Bakker et al 2008). This state of mind demonstrates a combination of three components i.e., vigour which is characterised by high levels of energy and cognitive resilience while working. A person with high level of vigour willingly invests effort in his or her work even in adverse situations. Another component is Dedication that indicates a sense of importance, keenness, pride, inspiration and challenge. The third component is Absorption that indicates a person who is happily engrossed in his/ her task and has problem in disengage himself/herself from work as the duration of time spent (Bakker 
et al, 2008). The Engaged employees are self-motivated physically, emotionally and cognitively to perform various task at the workplace (Kahn, 1990).

Research conducted in the past to identify the relationships between some of the personality traits and engagement using Big five traits of personality reflect that conscientiousness is a significant predictor of job engagement (Kim, Shin and Swanger, 2009). It was also hypothesized by Kim, Shin and Swanger (2009) that Agreeableness could also be a predictor of the engagement, which turned to be an insignificant result. It was identified that having said that agreeableness was not a predictor, but it slightly has a positive impact on the Dedication, and Conscientiousness positively influence the three dimensions (vigor, Dedication and Absorption) and Neuroticism. Nevertheless, Agreeableness was not a predictor of Work Engagement, it was observed that it had a slightly positive influence on Dedication, whereas Conscientiousness positively influenced the three engagement dimensions (Vigour, Dedication and Absorption). Further it was identified that Neuroticism influence Vigour negatively. Sun Li; Bunchapattanasakda Chanchai (2019) in their study suggests that the cognitive components such as dedication and involvement, and emotional components in the engagement reflect the attitudes of the employees, whereas vigour and absorption put emphasis on the employees' physical input and demonstrates through employee behaviour.

$\mathrm{H} 2.1$ : There is a significant relationship between extraversion; and engagement.

$\mathrm{H} 2.2$ : There is a significant relationship between openness to experience and engagement.

$\mathrm{H} 2.3$ : There is a significant relationship between agreeableness and engagement.

$\mathrm{H} 2.4$ : There is a significant relationship between conscientiousness and engagement.

$\mathrm{H} 2.5$ : There is a significant relationship between neuroticism and engagement.

\section{Work Values and Engagement}

A work value demonstrates what the necessities for working individuals are and what their expectation from the work is. Work values are evolved during the career development and may lean on the wellbeing related to the job. Research suggests that work values are coherent to work performance and job satisfaction (Chen and Kao, 2012; Tomaževič et al., 2018).Further ,work engagement indicates an affirmative fulfilling state of mind related to work and is demonstrated by vigour, dedication and absorption and positively correlates with intrinsic motivation (Schaufeli et al., 2002).

Bakker et al., (2008) suggests a difference between engaged and unengaged employee related to individual assets like autonomy, self- esteem, self-efficacy and optimism. They also opined that an engaged employee at workplace is inclined to perform both in -role and extra role behaviour (Bakker and Schaufeli, 2008).Sortheix et al., (2013); Schreurs et al., (2014). Saito et al., (2018) in their study suggests that engaged employees are more inclined towards intrinsic work values and rewards

H3: There is a significant relationship between work values and engagement.

H4: Work values moderate the relationship between the personality dimensions (a. extraversion; b. openness to experience; c. agreeableness; d. conscientiousness; e. neuroticism) and engagement 


\section{Method}

\section{Sample and Procedure}

The presented study is based on causal research design in which hypothesis testing was done. The data for the study was collected from the entry level working professionals who completed their studies and joined their organizations within last 12 months. The data was collected in four months from November 2020 to February 2021 and the researchers used convenience sampling technique due to quick data collection and easy accessibility. For the purpose of data collection, the researchers approached placement department of six different professional educational institutions and among them three educational institutions took part in data collection. The data was collected through online mode by sending a link of questionnaire to the respondents. The placement department of these three institutions send emails to immediate passing out students who got placed as a working professional in different organizations. The covering note in the email explained about the purpose of the data collection along with their consent for the same.

The data was collected in two phases $\mathrm{T} 1$ and $\mathrm{T} 2$ with a gap of 15 days to overcome the problem of CMV. In phase T1 the questionnaire included the items related to demographic variables and predictor variable (dimensions of personality), whereas in T2 phases the questionnaire contained items related to moderator (work values) and outcome variable (engagement). In phase T1 the 408 emails were sent whereas in phase T2 392 emails were sent. Out of which in the phase T1 325 and in T2 307 filled questionnaire were received. Out of the collected responses only 268 deemed fit for data analysis purpose as these responses were from the respondents of less than 23 years of age (Generation Z).

\section{Measure}

For the purpose of data collection two different instruments were used. In order to assess personality attributes viz. extraversion, openness to experience, agreeableness, conscientiousness and neuroticism, John and Srivastava' (1999) Big five model inventory of 44 items was used and to assess work values a 45 items scale suggested by Super (1970) was used. Whereas, to assess the dimensions of engagement i.e. vigour, dedication and absorption, Schaufeli and Bakkar's Utrecht work engagement scale (UWES) (2003) was used.

\section{Data Analysis and Results}

For data analysis SPSS 20 and AMOS 24 were used and the study included descriptive analysis using mean and standard deviation, EFA and CFA for scale reliability correlation analysis and hierarchical multiple regression analysis understand the characteristics, behaviour of sample collected and hypothesis testing. The sample for the study included $58.6 \%$ males and $41.4 \%$ females. All the respondents were postgraduate, whereas $76.8 \%$ were management graduates and $23.2 \%$ were IT graduates. Among the respondents $83 \%$ were 23 years of age whereas $17 \%$ were of 22 years of age. Apart from it $26.9 \%$ of the respondents were from $0-5$ lakh rupees, $49.5 \%$ were from 06- 10 Lakh rupees, $19.2 \%$ were from 11-15 lakh rupees, $1 \%$ were from 16-20 Lakh and 1.4\% were 21-25 Lakh rupees annual family income group. 
Table I present the descriptive statistics including mean and standard deviation of all seven variables involved in the study.

Table 1

Descriptive Statistics

\begin{tabular}{|c|c|l|c|c|c|c|c|}
\hline $\begin{array}{c}\text { S. } \\
\text { No. }\end{array}$ & Variable & Mean & $\begin{array}{c}\text { Standard } \\
\text { Deviation }\end{array}$ & $\begin{array}{c}\text { Factor Loading } \\
\text { range }\end{array}$ & $\begin{array}{c}\text { Cronbach's } \\
\text { alpha }\end{array}$ & AVE & CR \\
\hline 1 & Extraversion & 27.69 & 2.95 & $0.61-0.74$ & 0.79 & .61 & .87 \\
\hline 2 & $\begin{array}{c}\text { Openness to } \\
\text { Experience }\end{array}$ & 36.11 & 4.26 & $0.76-0.81$ & 0.82 & .63 & .88 \\
\hline 3 & Agreeableness & 32.03 & 3.37 & $0.71-0.76$ & 0.71 & .59 & .75 \\
\hline 4 & Conscientiousness & 30.06 & 3.43 & $0.62-0.75$ & 0.74 & .59 & .75 \\
\hline 5 & Neuroticism & 26.20 & 3.01 & $0.64-0.73$ & 0.73 & .62 & .89 \\
\hline 6 & Work Values & 177.84 & 16.85 & $0.60-0.79$ & 0.71 & .52 & .72 \\
\hline 7 & Engagement & 46.65 & 7.7 & $0.61-0.76$ & 0.81 & .61 & .87 \\
\hline
\end{tabular}

Source: Author's compilation

\section{Control Variable}

Following existing studies on the demographic factors affecting the engagement of the students, few variables have been considered as the control variables in the presented study. Variables such as gender of the respondents (Lietaert et al., 2015) and age group (Gibson and Slate, 2010) along with the specialization and family income group have been controlled during analysis.

\section{Reliability and Validity}

For the purpose of scale reliability by observing internal consistency, the value of Cronbach's alpha and composite reliability along with average variance explained (AVE) were calculated for all the seven variables included in the study. Table I depicts the value of Cronbach's alpha ranged between 0.71-0.82, which is more than the conventional cut-off value of 0.70 (Hair et al., 2006). The value of average variance explained (AVE) is observed as more than 0.50 (Hair et al., 2006) and composite construct reliability also ranged between $0.72-0.89$ which is also more than the recommended value of 0.70 (Bagozzi and Yi, 1988).

\section{Hypothesis Testing}

Correlation analysis was done to analyse the relationship between different variables in the study. The correlation coefficient basically a statistical measure of the degree to which changes in the value of one variable may predict the changes in the value of another variable. Table II present the results of hypothesis testing of H1.1 to H1.5, H2.1 to H2.5; and H3. 
Table 2

\section{Correlation Analysis}

\begin{tabular}{|c|c|c|c|c|c|c|c|}
\hline $\begin{array}{l}\text { S. } \\
\text { No. }\end{array}$ & Variable & 1 & 2 & 3 & 4 & 5 & 6 \\
\hline 1 & Extraversion & 1 & & & & & \\
\hline 2 & $\begin{array}{l}\text { Openness to } \\
\text { Experience }\end{array}$ & $0.415 * *$ & 1 & & & & \\
\hline 3 & Agreeableness & $0.498 * *$ & $0.315^{*}$ & 1 & & & \\
\hline 4 & Conscientiousness & $0.297 * *$ & $0.297 *$ & $0.379 * *$ & 1 & & \\
\hline 5 & Neuroticism & $0.298 * *$ & 0.101 & $0.289 * *$ & $0.303 * *$ & 1 & \\
\hline 6 & Work Values & $0.316^{*}$ & $0.421 * *$ & $0.326 * *$ & 0.285 & -0.215 & 1 \\
\hline 7 & Engagement & $0.327 * *$ & $0.398 * *$ & $0.315 * *$ & -0.215 & $0.236^{*}$ & $0.495 * *$ \\
\hline
\end{tabular}

(** Correlation is significant at the 0.01 level; * Correlation is significant at the 0.05 level) Source: Author's compilation

During analysis, the relationship of all personality elements/dimensions including extraversion, openness to experience, agreeableness, conscientiousness, and neuroticism with work values and engagement was done. A significant relationship was observed between extraversion, openness to experience and agreeableness and work values. Whereas, conscientiousness and neuroticism were found insignificantly related to work values. Thus, null hypothesis H1.1, H1.2, H1.3 is rejected whereas H1.4, H1.5, can't be rejected. Similarly, for analysing the relationship between all five personality dimensions with engagement, $p$ values for conscientiousness were found insignificant ( $p>.01 / p>.05$ ) thus H2.4 null hypotheses can't be accepted. Whereas H2.1, H2.2, H2.3 and H2.5 were rejected on the basis of significant $\mathrm{p}$ values such as $0.009,0.009,0.000$ and 0.35 for relationship between engagement and extraversion, openness to experience, agreeableness and neuroticism respectively.

Table 3

Summary Of Hypothesis Testing Based on Relationship

\begin{tabular}{|l|l|c|c|c|}
\hline Hypothesis & Relationship & $\begin{array}{c}\text { Correlation } \\
\text { Coefficient }\end{array}$ & $\begin{array}{c}\text { P } \\
\text { Value }\end{array}$ & Result \\
\hline H1.1 & Extraversion and Work values & $0.316^{*}$ & .037 & Reject Null \\
\hline H1.2 & $\begin{array}{l}\text { Openness to experience and Work } \\
\text { values }\end{array}$ & $0.421^{* *}$ & .001 & Reject Null \\
\hline H1.3 & Agreeableness and Work values & $0.326^{* *}$ & .001 & Reject Null \\
\hline H1.4 & Conscientiousness and Work values & 0.285 & .082 & Accept Null \\
\hline H1.5 & Neuroticism and Work values & -0.215 & .605 & Accept Null \\
\hline H2.1 & Extraversion and Engagement & $0.327^{* *}$ & .009 & Reject \\
\hline
\end{tabular}




\begin{tabular}{|l|l|c|c|c|}
\hline H2.2 & $\begin{array}{c}\text { Openness to experience and } \\
\text { Engagement }\end{array}$ & $.398^{* *}$ & .009 & Reject Null \\
\hline H2.3 & Agreeableness and Engagement & $0.315^{*}$ & .000 & Reject Null \\
\hline H3.4 & Conscientiousness and Engagement & -0.215 & .155 & Accept Null \\
\hline H3.5 & Neuroticism and Engagement & $-0.236^{*}$ & .035 & Reject Null \\
\hline H4.1 & Work Values and Engagement & $0.495^{* *}$ & 0.00 & Reject Null \\
\hline
\end{tabular}

Source: Author's compilation

Table III presents the summary of the entire hypothesis testing done using correlation analysis. Mostly moderate relationship was observed between variables wherever a significant relationship was found.

\section{Hierarchical Multiple Regression Analysis}

For testing the fourth hypothesis of the presented study, hierarchical multiple regression was used. During the multiple regression, the interaction effect of each personality dimension i.e., extraversion, agreeableness, conscientiousness, neuroticism and openness to experience and work values was supposed to be explored to find out the effect of such interaction on engagement. However, the correlations between conscientiousness, neuroticism with work values and engagement were found insignificant. Thus, for further analysis the personality dimensions, conscientiousness and neuroticism were dropped from the hierarchical multiple regression analysis.

Table 4

\section{Hierarchical Multiple Regression}

\begin{tabular}{lccc}
\hline \multicolumn{4}{c}{ Engagement } \\
\hline & Model 1 & Model 2 & Model 3 \\
\hline Model Variables & & & \\
\hline Extraversion & 0.381 & 0.397 & 0.41 \\
Openness to experience & 0.37 & 0.35 & 0.41 \\
Agreeableness & 0.29 & 0.21 & 0.24 \\
Neuroticism & -0.31 & -0.27 & -0.23 \\
\hline Moderating Variable & & & \\
\hline Work value & & 0.31 & 0.4 \\
\hline Interaction effects & & \\
\hline Extraversion X work values & & 0.34 \\
Openness to experience X Work values & & & 0.39 \\
Agreeableness X Work values & & & 0.31 \\
Neuroticism X Work values & & -0.21 \\
\hline F Change & $20.01^{* *}$ & $21.81^{* *}$ & $19.64 * *$ \\
R Square & 0.32 & 0.43 & 0.52 \\
R square change & 0.31 & 0.11 & 0.19 \\
\hline
\end{tabular}

$* \mathrm{p}<0.05, * * \mathrm{p}<.01$.

Source: Author's compilation 
The results of the hierarchical multiple regression are presented in the table IV. First model of the study included only four personality dimensions and its impact on engagement was observed in terms of coefficient of determination. The value of the same appeared as $(* * p<0.1)$ 0.31 representing $31 \%$ change in engagement due to the presence of four personality dimensions i.e., extraversion, agreeableness, openness to experience and neuroticism. To find out the impact of work values on engagement second model was run and an additional variance of $11 \%(* * \mathrm{p}<0.1)$ was observed as the value of $\mathrm{R}$ square change increased from 0.32 to 0.43 . Later to find out the moderating/interacting effect of work values on the association with personality dimensions i.e. extraversion, agreeableness, openness to experience, and neuroticism and engagement, third regression model was run. It is observed in the table from third model that value of $\mathrm{R}$ square appeared as $0.52(* * \mathrm{p}<0.1)$, which means an additional change in engagement is observed due to interaction effect between personality variables and work values. As all the five personality dimensions were not considered in the study the H4 is considered as partially accepted.

\section{Discussion}

The focus of the research was to investigate association between personality dimensions, work values and engagement attributes. It also investigated moderating effect of work values on the relationship between personality dimensions and engagement. As there are five personality dimensions studied in this research work, the outcome of the study is explained below in reference to their relationship with work values and engagement. During the correlation analysis between all five personality dimensions and work values the results indicated that except conscientiousness and neuroticism, all the three dimensions are significantly related to work values.

Extraversion was found significantly related with work values and the findings from current study also validate the study by Furnham, Forde, and Ferrari (1999). Whereas it contradicts with Furnham et al. (2002) as they mentioned conscientiousness as the best predictor of work values. There is lack of previous studies on the individual relationships between personality dimensions and work values, the authors suggest that this relationship is based on selfdetermination theory (Ryan and Deci, 2000). As per the theory a motivated individual integrates their personality characteristics and with the presented study validates the same with the results. In this study the respondents who are immediate passing out students, from post graduate courses that recently joined employment. These respondents are in the beginning of their career; thus, they may have high enthusiasm, with an open attitude to new experiences of learning especially with agreeable attitude. There are fair chances that they moderated their behaviour and ultimately integrated their personality traits which can be a good match between organizational values and work values of individuals belonging to generation $\mathrm{Z}$.

Further during Analysis, except conscientiousness all other personality dimensions including extraversion, openness to experience, agreeableness and neuroticism are found to be significantly related with engagement. During analysis neuroticism was found to be negatively significant with engagement. This particular outcome of the research validates the findings of 
previous research (Kim, Shin and Swanger, 2009; Langelaan et al. 2006). It may be because of negative motions among the neurotic individuals (Watson, 2000). The positive relationship between extraversion and openness to experience with engagement may be found due to the energy and enthusiasm, in an individual towards the job role. A person who is open to explore, generally get along with other's thoughts and are full of excitement to interact with others. They would certainly develop high level of vigour among themselves and such people may be quite devoted and involved to the assignment they get. It may further be understood that extraversion and sincere approach towards work may also result in conflicting situation at workplace. However, in case they are dedicated, they develop agreeable attitude and due to such attitude, they are interested in exploring and experiencing new things, and keep on contributing to the job roles.

During study the effect of personality attributes on work values was partially observed through openness to experience and agreeableness. Along with it, except neuroticism all other personality dimensions have significant effect on engagement of employees. The findings related to effect on work values may be due to positive and negative aspects of personality. Similarly, on engagement except neuroticism a negative aspect of personality dimension all other positively affect the engagement.

Furthermore, an affirmative association was also identified between work values and engagement. These findings are in conformity with the results of previous studies by Saito et al. (2018); Schreurs et al. (2014); and Sortheix et al. (2013). Along with it a partial moderating effect of work values was also observed between the relationship of personality dimensions and engagement. As a significant relationship between conscientiousness and engagement could not be observed while calculating interaction effect, the personality dimension conscientiousness was dropped. The interaction effect of all work values on the relationship between all other personality dimension i.e., extraversion, openness to experience, agreeableness and neuroticism with engagement was found significant. Thus, partial moderating effect was observed. As per self-determination theory (Ryan andDeci, 2000) for innate needs such as needs of relatedness to affect work outcomes constructively, an individual requires certain level of intrinsic motivation. An engaged employee possesses such intrinsic motivation. It further validates the findings of the current study.

\section{Limitation and Suggestions for Future Research}

The study has examined, verified, and confirmed the association between personality dimensions, work values and engagement attributes namely vigour, dedication and absorption. The study discussed the possible relationship between personality dimensions with work values and engagement attributes. It also investigated the effect of personality dimensions on work values and engagement. It can be concluded that there is a partial effect of personality dimensions on work values except neuroticism; all other personality dimensions are responsible for engagement of employees at the workplace. 
This study can't be considered free from any limitation. There is limitation in terms of sample and design. The outcomes of the study are based on the primary data collected from passing out students, who recently joined organizations after placement. The generalization of the results can be done better with the increased sample size in future studies. Future studies may also include the respondents from different geographical locations and different industries. Further, it may include longitudinal research design based on the primary data from the corporate professionals in different stages of their career.

\section{Managerial Implications}

The study offers theoretical and practical implications. The outcome of the presented study contributes to the literature in many ways. This study contributes to the literature by demonstrating the relationships between personality dimensions and work values along with personality dimensions and engagement. There is a lack of previous studies examining moderating/interacting effect work values on the association among personality dimensions and engagement. Thus, by introducing work values as moderator in the association with personality dimensions and engagement, the scholars can gain insight about whom engagement relates to.

These days, the organisations are quite concerned about and trying to create compatibility between organizational values and work values of an employee along with their engagement level on the job assignment. Though there are various predictors that play a pertinent role in employee's work values and engagement however, this study focuses on individual's related aspect of predictors. All such predictors include personality dimensions as well. The study suggests that the engagement of an employee may enhance due to interaction effect between work values and personality dimensions. The findings suggest to the Human Resource (HR) practitioners that they can offer mutual benefits. As they can conduct personality test using psychometric analysis and then possibly predict the work values and engagement among employees. The roles of practitioners are getting more complex in coming years as they need to have an engaged workforce. In such circumstances the findings may prove to be a part of predictive analysis.

\section{References}

- Andrea, B, Gabriella. H-C and Timea, J. (2016), "Y and Z Generations at Workplaces", Journal of Competitiveness, Vol. 8 No. 3, pp. 90-106.

- Bagozzi, R. P. and Yi, Y. (1988), "On the evaluation of structural equation models", Journal of the academy of marketing science, Vol. 16 No. 1, pp. 74-94.

- Bakker, A. and Oerlemans, W. (2012), "Subjective well-being in organizations," in The Oxford Handbook of Positive Organizational Scholarship, eds K. S. Cameron and G. M. Spreitzer (New York, NY: Oxford University Press), 178-189.

- Bakker, A., Schaufeli, W., Leiter, M. and Taris, T. (2008), "Work engagement: An emerging concept in occupational health psychology", Work and Stress, Vol. 22, pp. 187-200. 
- Bascha.(2011). Z: The open-source generation. Retrieved from http://opensource.com/business/11/9/z-open-source-generation

- Bond, S. (2016), "The new rules of engagement", International Journal of Market Research, Vol. 58 No. 3, pp. 351-353.

- Brown, D. (1996). Brown's values-based, holistic model of career and life-role choices and satisfaction. In D. Brown and L. Brooks (Eds.), Career Choice and Development (pp. 337-372). San Francisco, CA: Jossey-Bass.

- Brue Tulganand Rain Maker Thinkign Inc. (2013). Meet Generation Z: The second generationwithin the giant "Millennial" cohort Retrieved from http://rainmakerthinking.com/assets/uploads/2013/10/Gen-Z Whitepaper.pdf.

- Buckingham, M. and Coffman, C. (1999). First, Break All the Rules, Simon and Schuster, New York.

- Chen, C. F., and Kao, Y. L. (2012). Moderating effects of work engagement and job tenure on burnout-performance among flight attendants. Journal of Air Transport Management, 25, 6163.

- Christian, M.S., Garza, A.S. and Slaughter, J.E. (2011), "Work engagement: a quantitative reviewand test of its relations with and contextual performance", Personnel Psychology, 64(1), 89-136.

- Costa PT, McCrae RR (1992). Revised NEO Personality Inventory (NEO-PI-R) and NEO Five-Factor (NEO-FFI) professional manual. Odessa, Florida: Psychological Assessment Resources.

- Côté, S., and Miners, C. T. H. (2006). Emotional Intelligence, Cognitive Intelligence, and Job Performance. Administrative Science Quarterly, 51(1), 1-28

- Deci, E. L., and Ryan, R. M. (2000). The "what" and "why" of goal pursuits: Human needs and the self-determination of behavior. Psychological Inquiry, 11, 227-268.

- Deci, E. L., and Ryan, R. M. (2012). Self-determination theory. In P. A. M. Van Lange, A. W. Kruglanski, and E. T. Higgins (Eds.), Handbook of theories of social psychology (p. 416-436). Sage Publications Ltd. https://doi.org/10.4135/9781446249215.n21

- Deci, E. L., Eghrari, H., Patrick, B. C., and Leone, D. R. (1994). Facilitating internalization: The self-determination theory perspective. Journal of personality, 62(1), 119-142.

- Dries, N., Peppermans, R., and De Kerpel, E. (2008). Exploring four generations beliefs about career Is "satisfied" the new "successful”? Journal of Managerial Psychology. 23(8), 907-928.

- Elizur, D. (1984). Facets of work values: A structural analysis of work outcomes. Journal of Applied Psychology, 69, 379-389. http://dx.doi.org/10.1037/0021-9010.69.3.379

- Fleming, J.H. and Asplund, J. (2007), Human sigma, Gallup Press, New York, NY

- Furnham, A., Forde, L., and Ferrari, K. (1999). Personality and work motivation. Personality and Individual Differences, 26, 1035-1040.

- Furnham, A., Petrides, K. V., Jackson, C. J., and Cotter, T. (2002). Do personality factors predict job satisfaction? Personality and Individual Differences, 33(8), 1325-1342.

- Ghura, S. A, (2017). A Qualitative Exploration of the Challenges Organisations Face while working with Generation Z Intrapreneurs, Journal of Entrepreneurship and Innovation in Emerging Economies, 3(2), 105-114 
- Gibson, A. M., and Slate, J. R. (2010). Student engagement at two-year institutions: Age and generational status differences. Community College Journal of Research and Practice, 34(5), 371-385.

- Goldberg LR (1981). Language and individual differences: The search for universals in personality lexicons. In: Wheeler (Ed.), Beverly Hills, CA: Sage. Rev. Pers. Soc. Psychol. 1:141-165.

- Goldberg, L., (1990). An alternative "description of personality": The Big-Five factor structure. Journal of Personality and Social Psychology, 59, 1216-1229.

- Goldberg, L.R. (1992). The development of markers for the big-five factor structure. Psychological Assessment, 4, 26-42. http://dx.doi.org/10.1037/1040-3590.4.1.26.

- Hair, J. F., Black, W. C., Babin, B. J., Anderson, R. E., and Tatham, R. (2006). Multivariate data analysis. Upper saddle River.

- Hofstede, G. (1980a). Cultural consequences: International differences in work-related values. Sage, CA: Newbury Park.

- Holbeche, L. and Springett, N. (2003), In Search of Meaning in the Workplace, Horsham, Roffey Park Institute, ISBN: 0907416527.

- Hughes, J. (2020), Need to Keep Gen Z Workers Happy? Hire a 'Generational Consultant.' The New York Times Magazine.

- Inceoglu I, Warr P (2012). Personality and Job Engagement. Journal of Psychology, 1-9.

- Inceoglu, I., andWarr, P. (2011). Personality and job engagement. Journal of Personnel Psychology, 10, 177-181

- Jaskyte. K. (2014) Individual and Work Values of Nonprofit, Public, and Business Employees: How Similar or Different Are They? Human Service Organizations: Management, Leadership and Governance. 38(3), 283-296.

- John, O. P., and Srivastava, S. (1999). The Big Five trait taxonomy: History, measurement, and theoretical perspectives. Handbook of personality: Theory and Research, 2(1999), 102- 138.

- Judge, T. A., Higgins, C. A., Thoresen, C. J., and Barrick, M. R. (1999). The big five personality traits, general mental ability, and career success across the life span. Personnel psychology, 52(3), 621-652.

- Kahn, W., (1990). Psychological conditions of personal engagement and disengagement at work. Academy of Management Journal, 33, 692-724.

- Kim, H., Shin, K. and Swanger, N., (2009). Burnout and engagement: A comparative analysis using the Big Five personality dimensions. International Journal of Hospitality Management, 28, 96-104.

- Kinicki, (2008). Organizational Behavior: Core Concepts, New York, McGraw-Hill Irwin

- Kluckhohn, C. (1951) Values and Value-Orientations in the Theory of Action: An Exploration in Definition and Classification. In: Parsons, T. and Shils, E., Eds., Toward a General Theory of Action, Harvard University Press, Cambridge, 388-433. http://dx.doi.org/10.4159/harvard.9780674863507.c8

- Langelaan, S., Bakker, A., van Doornen, L. and Schaufeli, W., (2006). Burnout and work engagement: Do individual differences make a difference? Personality and Individual Differences, 40, 521-532. 
- Le Pine, J.A., Colquitt, J.A., and Erez, A. (2000). Adaptability to changing task contexts: Effects of general cognitive ability, conscientiousness, and openness to experience. Personnel Psychology, 53, 563-593.

- Leiter, M.P. and Bakker, A.B. (2010), "Work engagement: introduction”, in Bakker, A.B. and Leiter, M.P. (Eds), Work engagement: A Handbook of Essential Theory and Research, Psychology Press, Hove, pp. 1-9.

- Lesthaeghe R. and Moors G. (2000). Life course transitions and value orientations: Selection and adaption. Presented at contact forum: Values Orientations and Life Cycle Decisions, Results from Longitudinal Studies, Brussels.

- Levy, S. and Guttman, L. (1976). Values and attitudes of Israeli high school children. The Israel Institute of Applied Social Research, Jerusalem (Hebrew translation).

- Lewin, K. (1951). Field Theory in Social Science. Harper and Row: New York

- Lichtenstein, Scott and Lichtenstien, G. and Higgs, M. (2017) Personal values at work: a mixed-methods study of executives' strategic decision-making, Journal of General Management, 43(1) 15-23.

- Lietaert, S., Roorda, D., Laevers, F., Verschueren, K., and De Fraine, B. (2015). The gender gap in student engagement: The role of teachers' autonomy support, structure, and involvement. British Journal of Educational Psychology, 85(4), 498-518.

- Liu, Z. A. (2016). Study on the development of structure model of engagement for knowledge employee. Business management, 11, 65-69. http://dx.doi.org/10.13395/j.cnki.issn.10090061.2016.11.018

- Locke, E. A. (1976). The nature and causes of job satisfaction. In M. D. Dunnette (Ed.), Handbook of industrial and organizational psychology (pp. 1297-349). Chicago: Rand McNally.

- Luthans, F. and Peterson, S.J. (2002), Employee engagement and manager selfefficacy, Journal of Management Development, 21(5), 376-387.

- Lyons, S., Higgins, C. and Duxbury, L. (2010), Work values: development of a new threedimensional structure based on confirmatory smallest space analysis, Journal of Organizational Behaviour, 31(7), 969-1002.

- Macey, W. and Schneider, B., (2008). The meaning of employee engagement. Industrial and Organizational Psychology, 1, 3-30.

- Malcolm Higgs, Scott Lichtenstein (2011); Is there a Relationship between Emotional Intelligence and Individual Values? An Exploratory Study; Journal of Management, 37(1), 65-79.

- McCrae RR, John OP (1992). An introduction to the Five-Factor Model and its applications. Journal of Personality, 60(2), 175-215.

- Nikolaou, I., and Robertson IV, I. T. (2001). The five-factor model of personality and work behaviour in Greece. European Journal of Work and Organizational Psychology, 10(2), 161186.

- Olson, J. M. and Zanna, M. P. (1993). Attitudes and attitude change. Annual Review of Psychology, 44, 117-54. http://dx.doi.org/10.1146/annurev.ps.44.020193.001001

- Pennings, I. M. (1970). Work value systems of white-collar workers. Administrative Science Quarterly, 15, 397-405. http://dx.doi.org/10.2307/2391330 
- Rana,S., Pant,D., Chopra,P.,(2019) Work Engagement and individual Work Performance research findings and an Agenda for Employee Relationships, Journal of Emerging Technologies and Innovative Research (JETIR ), 6(5).

- Rich, B. L., Lepine, J. A., and Crawford, E. R. (2010). Job engagement: Antecedents and effects on job performance. Academy of management journal, 53(3), 617-635.

- Richman, A. (2006), Everyone wants an engaged workforce how can you create it?, Workspan, 49(1), 36-39.

- Roberts, D. R. and Davenport, T. O. (2002). Job engagement: Why it's important and how to improve it, Published online at Wiley Interscience, 21-29

- Rokeach, M. (1973). The nature of human values. New York, NY: The Free Press.

- Rosenberg, M. (1957). Occupations and Values, Glencoe, Illinois: Free Press.

- Ryan, R. M., andDeci, E. L. (2000). Self-determination theory and the facilitation of intrinsic motivation, social development, and well-being. American Psychologist, 55(1), 68-78.

- Saito, Y., Igarashi, A., Noguchi-Watanabe, M., Takai, Y., and Yamamoto-Mitani, N. (2018). Work values and their association with burnout/work engagement among nurses in long-term care hospitals. Journal of Nursing Management, 26(4), 393-402.

- Schaufeli, W. B., Salanova, M., González-Romá, V., and Bakker, A. B. (2002). The measurement of engagement and burnout: A two sample confirmatory factor analytic approach. Journal of Happiness Studies, 3(1), 71-92.

- Schaufeli, W. B., and Bakker, A. B. (2003). Utrecht Work Engagement Scale: Preliminary Manual. Utrecht: Utrecht University.

- Schreurs, B., Van Emmerik, I. J., Van den Broeck, A., and Guenter, H. (2014). Work values and work engagement within teams: The mediating role of need satisfaction. Group Dynamics: Theory, Research, and Practice, 18(4), 267.

- Schwartz, S. H. (1994). Are there universal aspects in the structure and content of human values? Journal of Social Issues, 50, 19-45. http://dx.doi.org/10.1111/j.15404560.1994.tb01196.x

- Simmons, D.R. (2018), "Work values across generations among construction professionals in the United States", Journal of Construction Engineering and Management, 144(10), 04018096, doi: 10.1061/(ASCE)CO.1943-7862.000155

- Singh A. and Shukla T. (2019), The Mediating Effect of Employee Engagement Practices: An Evidence Based Research, ISBN: 978-93-86238-65-8, Excellent Publishing House, 226-230.

- Singh, A. and Shukla, T. (2012), Employee Engagement in an Indian Tin Manufacturing: An Investigation, Asian Journal of Management Sciences and Education (AJMSE), 1(3), 80-93.

- Singh, L. B. (2017). Job satisfaction as a predictor of Employee engagement. Amity Global HRM Review, 7(1), 20-30.

- Singh, L. B., Kumar, A., and Srivastava, S. (2020). Academic burnout and student engagement: a moderated mediation model of internal locus of control and loneliness. Journal of International Education in Business.

- Sortheix, F. M., Dietrich, J., Chow, A., and Salmela-Aro, K. (2013). The role of career values for work engagement during the transition to working life. Journal of Vocational Behavior, 83(3), 466-475 
- Spreitzer, G., and Porath, C. (2014). "Self-Determination as a nutriment for thriving: building an integrative model of human growth at work," in The Oxford Handbook of Work, ed. M. Gagne (New York, NY: Oxford University Press), 245-254.

- Srivastava, S., and Bajpai, L. (2020). Linking conservation of resource perspective to personal growth initiative and intention to leave: role of mediating variables. Personnel Review.

- Sun Li; Bunchapattanasakda Chanchai (2019) Employee Engagement: A Literature Review International Journal of Human Resource Studies, 9(1), 63-80.

- Super, D. E. (1970). Manual Work Values Inventory Work Values Inventory. Houghton Mifflin, New York. 30(1) 141-145.

- Teresa Bridge. (2015). 5 Ways The workplace Needs To Change to Get The Most out Of Generation Z. Retrieved from http://www.fastcoexist.com/3049848/5-ways-the-workplaceneeds-to-change-to-get-the-most-out-of-generation-Z

- Tomaževič, N., Seljak, J., and Aristovnik, A. (2019). Occupational values, work climate and demographic characteristics as determinants of job satisfaction in policing. Police Practice and Research, 20(4), 376-393

- Tripathi, P. M., Srivastava, S., Singh, L. B., Kapoor, V., and Solanki, U. (2020). A JD-R perspective for enhancing engagement through empowerment: A study on Indian hotel industry. Journal of Hospitality and Tourism Management, 46, 12-25.

- Watson, D., (2000). Mood and temperament. New York: Russell Sage Foundation Press.

- Wefald, A. J., Mills, M. J., Smith, M. R. and Downey, R. G. (2012), A Comparison of Three Job Engagement Measures: Examining their Factorial and Criterion-Related Validity. Applied Psychology: Health and Well-Being, 4, 67-90.

- Ye, L. (2015). Work values and career adaptability of ChineseUniversity students. Social behaviour and personality: An international journal. 43(3), 411.

- Yuanjie Bao and Wei Zhong (2020): Work Values of Chinese MPA Students: Underlying Dimensions and Group Differences, International Journal of Public Administration, 43(11), 110.

- Yvonne Guerrier, Keith Macmillan (1981), Managers Values and Career Decisions, Journal of Management, 7(1), 22-3. 